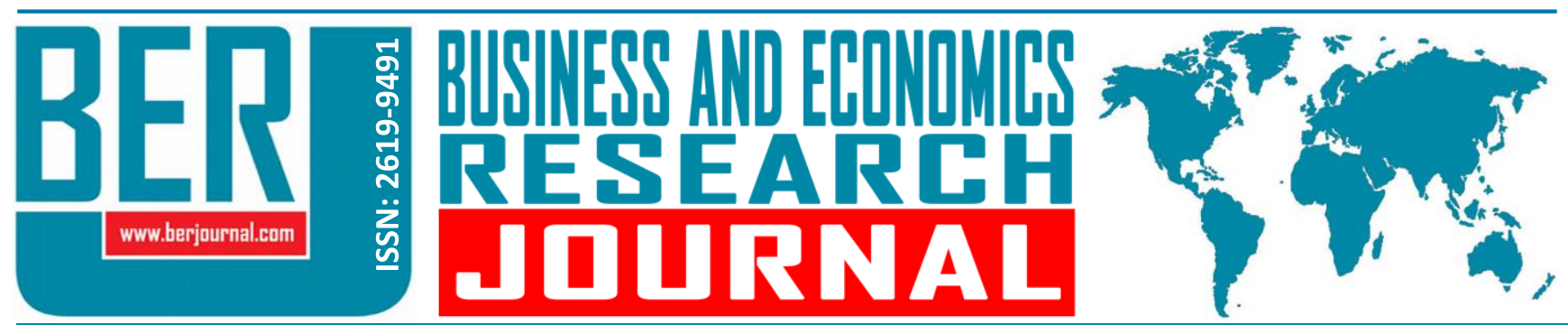

Business and Economics Research Journal Vol. 11, No. 2, 2020, pp. 323-334 doi: 10.20409/berj.2020.252

\title{
The Effects of Exchange Rates on CPI and PPI
}

\begin{abstract}
Akin Usupbeyli ${ }^{\mathrm{a}}$, Sefer Ucak $^{\mathrm{b}}$
Abstract: Strong correlation between exchange rate fluctuations and inflation rates in developing countries makes important to measure the impact of the exchange rate on domestic prices, especially for the countries applying an inflation targeting, like Turkey. Besides, in the countries having high import dependency in energy and intermediate goods, the transition of an increase in the exchange rates to domestic prices is complete. This study examines the effects of exchange rates (US Dollar) fluctuations (ER) on consumer price index (CPI) and producer price index (PPI) between 2003:01-2019:10 in Turkey. As ER series is [I(1)] and CPI and PPI series are [I(O)], ARDL model is applied. Results show that there exists a cointegration between the series and there is a bidirectional causality between CPI and ER; unidirectional relation from ER to PPI. No causality is detected from $P P I$ to $E R$. When the short-run relationship between $E R$ and $C P I$ is examined, it was found that a depreciation in ER in Turkey causes increase in CPI. Similar results are found for the relation between ER and PPI.
\end{abstract}

Keywords: Exchange Rate, Inflation, Consumer Price Index, Pass Through, ARDL Bounds Test

JEL: F10, F31, C10

\section{Introduction}

Nominal exchange rate for world economies ceased to be a policy instrument or an anchor with the transition from fixed exchange rate regimes to floating exchange rate regimes in the 1980s. However, this situation did not triviliase the effects of exchange rates, on the contrary, macroeconomic problems caused by volatility in exchange rates increased the importance of exchange rate. Thus, the "pass through" (PT) mechanism, which reflects effects of the fluctuations in exchange rates on prices, has started to find a vast place in the economic literature. While the studies conducted for developed countries related to PT focus on the effect of exchange rate fluctuations on external adjustment, studies in developing countries focused on transmission to the inflation.

In terms of transition to inflation, the PT mechanism refers to the percentage change in domestic prices caused by a one percent change in the exchange rate (Goldberg \& Knetter, 1996). Similarly, Menon (1994) defines exchange rate PT as "the degree to which exchange rate changes are reflected in the destination currency prices of traded goods." (Menon, 1994) As a result of purchasing power parity, the exchange rate pass-through needs to be complete. In his article Dornbusch (1987) states that this is only possible in perfectly competitive markets. In an oligopolistic market where competition is incomplete, exchange rate transition cannot be complete as firms can change not only their prices but also their profit margins due to strategic moves. (Dornbusch, 1987)

a Asst. Prof., PhD., Ankara University, Faculty of Political Sciences, Ankara, Turkiye, ausupbeyli@politics.ankara.edu.tr (ORCID ID: 0000-0003-2792-8805)

b Asst. Prof., PhD., Balıkesir University, Sindirgi Vocatıonal School, Balıkesir, Turkiye, seferucak@balikesir.edu.tr (ORCID ID: 00000002-9251-9584) 
The effects of exchange rate fluctuations on domestic prices are observed through the prices of imported goods. In small open countries, transition to price arises on both consumer and producer prices. The increase in the exchange rate (e.g. the depreciation of the national currency) will directly increase the consumer price index proportionate to the weight of imported consumer goods in the consumer index. Moreover, in countries with high dependence on imported intermediate inputs and energy, increase in the exchange rate will augment the producer price index through production costs and thus indirectly effect the prices of not only imported products but also the price of domestic products. Therefore, Menon (1996) stated that the primary factor determining the strength of PT effect is the level of substitution between a domestic product and an imported product (Menon, 1996).

Another negative impact of the price increases due to PT effect is the "indexation" effect for the countries experienced a long-term high inflation like Turkey. The increase in the exchange rate due to the indexing effect will disrupt price expectations and lead to an upward movement in prices. For a Central Bank adapted inflation targeting to combat inflation, deviating from the target will create forward-looking distrust. If Central Bank intervenes to exchange rate markets, in a floating regime, in order to prevent forward-looking distrust, it is called fear of floating by Calvo and Reinhart (2002). According to Calvo and Reinhart (2002), the problems that make developing countries different from developed countries when applying the exchange rate regime are that the existence of a large amount of foreign currency debt, high exchange rate transition on prices, negative effects of lack of competitiveness and credibility problems. Due to such problems, a developing country that has chosen the free-floating exchange rate regime can intervene directly or indirectly to the exchange markets, provided that it is not aimed at a certain exchange rate target. Otherwise, it is difficult to sustain a floating exchange rate regime. Therefore, predicting the level and maturity of PT is primordial for Central Banks to determine their monetary policy.

In the inflation report published by the Central Bank of Republic of Turkey (CBRT) in the first quarter of 2016 it is stated that a 10\% depreciation of Turkish lira against exchange rate basket caused an increase in inflation by 1.8 points Also, a positive shock of 10 percent on import prices in US dollars has also been shown to increase inflation by 1.3 percentage points at the end of two years (p.36). Similarly, the CBRT's first quarter inflation report for 2018 showed that one of the main reasons of rapid rise in consumer inflation is depreciation of the Turkish lira. The inflation report published for the third quarter of the same year indicated that despite the decline in aggregate demand, inflation reached a level of 24.52 percent. The reason for this increase is explained in the report as the effect of cost pressures caused by the depreciation of the Turkish lira on consumer prices.

Figure 1. CPI and PPI Series

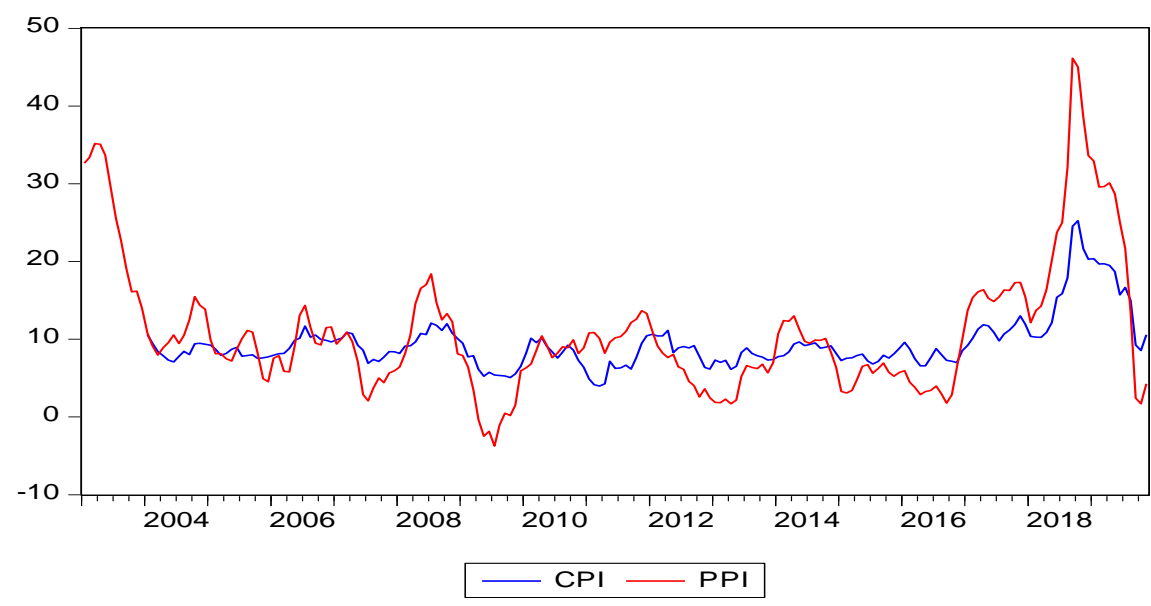

By the end of 2018, the inflation rate( percentage change in CPI) fell to 20.3 percent as it seen in Figure 1. In the last quarter report of 2018, the appreciation of the Turkish lira is the main reason of this decline as it seen in Figure 2. In all these reports, the emphasis on the relationship between exchange rate and inflation shows that the PT mechanism is also closely monitored by the CBRT. 
Figure 2. ER Series

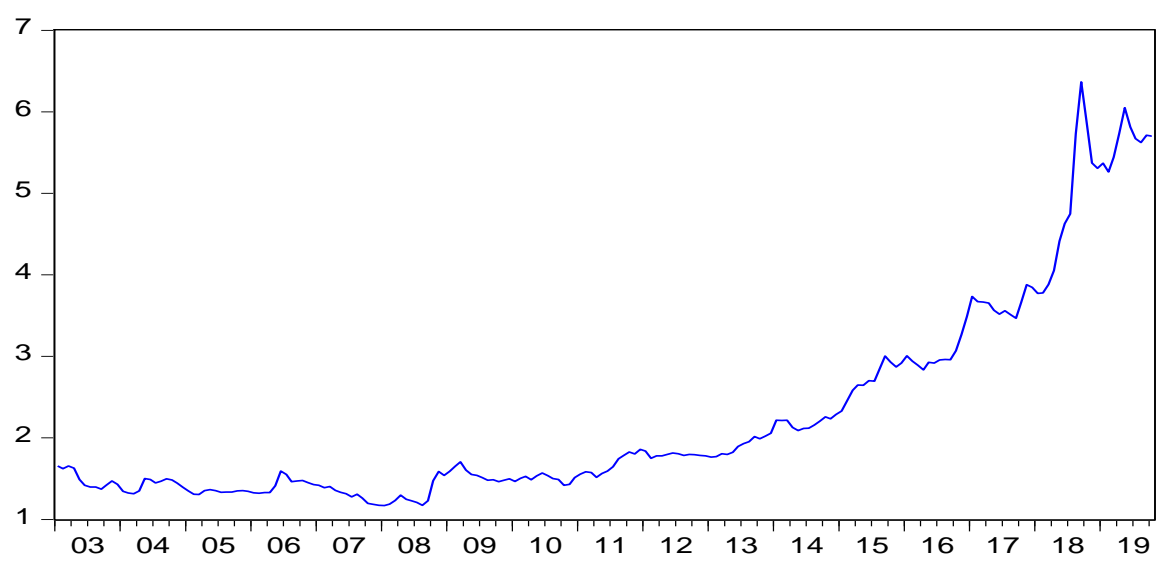

High dollarization and currency substitution in Turkey cause a strong PT mechanism. Many goods and services in Turkey are indexed to the dollar officially or unofficially. When examined, the sum of imported intermediate goods and capital goods is over 80 percent of the total imports. Furthermore, since Turkey is structurally an energy importer country, it is expected that exchange rate movements have a high influence in producer prices. In addition, continuous and high deviations from the inflation target cause firms to reflect the changes in exchange rates to prices very quickly. Moreover, the oligopolistic structure of Turkish industry causes wholesalers to reflect exchange rate changes to retailer swiftly.

In this study, the effects of changes in US dollars to consumer and producer prices are examined. The rest of the study is organized as follows. In the second part, literature review related to the subject is given. After that, the methodology and findings are discussed. Lastly, results are discussed, and the study is concluded.

\section{Literature Review}

When studies on PT effect are examined, the structure and size of the PT effect appears to be examined under different exchange rate policies. While the existing literature focuses on causality, it is also observed that dynamic methods such as Vector Autoregressive (VAR) methodology and cointegration methodology, which examine short and long term respectively, come to the fore as the method.

McCarthy (1999) examined the effects of exchange rate and import prices on consumer and producer prices using recursive VAR analysis in 6 industrialized OECD countries (Japan, Belgium, Netherlands, Sweden, Switzerland and England. In the study, it is observed that exchange rate has a limited effect on consumer prices, whereas import prices have a strong effect. McCarthy also demonstrated that the power of the PT mechanism is linked to the openness of the country.

Ito and Sato (2006) have examined the effects of the exchange rate shock caused by the Asian crisis and the followed monetary policies on domestic prices in 5 East Asian countries (Indonesia, Korea, Thailand, the Philippines, and Malaysia) (Ito \& Sato, 2008). According to the results of VAR analysis used in the study which examined the period of $1994-2006$, the effect of exchange rate shock on producer prices was greater than the effect on consumer prices. Ito and Sato (2006) stated that this is an expected result because the degree of pass-through depends on the degree of tradable contents. In addition, the authors argue that, as in the case of Indonesia, a possible recovery from a crisis is much more difficult in countries where the passthrough mechanism has a strong impact on CPI.

Zorzi et al. (2007) is conducted a study on 12 countries (China, South Korea, Singapore, Taiwan, Hong Kong, Czech Republic, Hungary, Poland, Argentina, Chile and Mexico) in Asia, Central and Eastern Europe, Latin America and Turkey (Zorzi, Hahn \& Sanchez, 2007). Johansen cointegration results do not show a longterm relationship, so the VAR analysis shows the effect of the PT mechanism in the price chain is gradually disappearing, thus import prices are more affected than consumer prices. The study also showed that the 
strength of the PT mechanism depends on the inflation rate of the country rather than the level of openness of the country. Therefore, the countries experiencing a relative high inflation such as Argentina and Turkey, have a stronger PT mechanism.

Dolores (2009) studied the PT effect in 11 East and Central European economies (Bulgaria, Cyprus, Czech Republic, Estonia, Hungary, Latvia, Lithuania, Poland, Romania, Slovakia, Slovenia) and Turkish economy with VAR methodology between 2000-2007 (María-Dolores, 2009). According to the results of the study, firstly, PT was found to be higher in developing countries than in developed countries. Secondly, in line with Taylor's hypothesis between inflation and transition, PT was lower in countries that have controlled inflation through inflation targeting, such as Hungary, Poland and the Czech Republic.

Using VAR model, Saha \& Zhang (2013) analyzed the pass-through of the exchange rate to import prices, producer prices and consumer prices in the Australian, Chinese and Indian economies between 1990 and 2011 (Saha \& Zhang, 2013). The results of the analysis showed that the PT level of consumer prices in the Australian economy is higher than that of the Chinese and Indian economies. However, while the depreciation of the exchange rate increased import prices in the Australian economy, contrary to expectations, in China and India this depreciation lowered the prices. The reason for this is stated that the determinants of inflation in China and India economies are internal factors such as money supply and production potential rather than external factors.

Halali et al. (2015) examined the short and long-term effects of fluctuations in Tunisian Dinar on import, consumer and producer prices between 1993 and 2011. (Halali, Kalai \& Boujelben, 2015) The study uses SVAR model and VECM, and found that the pass-through mechanism is strong in both short and long term in Tunisia. They considered the high dollarization in the country as the reason for this.

These studies conducted in structurally different economies have demonstrated the importance of PT mechanism in developed or developing countries. The factors determining the strength of the PT mechanism are the openness of the country, the current level of inflation, the competitive structure of the markets in the country and the severity of dollarization.

Similarly, many studies have been conducted in order to investigate the PT mechanism in Turkey. In their study, Leigh and Rossi (2002) uses recursive VAR method to investigate the effect of exchange rate changes on producer and consumer prices just after the transition to floating exchange rate regime by the end of February 2001 crisis. It is showed that PT mechanisms is very strong in first 4 months and completed over a period of 11 months. Also, the effects of the change in exchange rates on producer prices were stronger than consumer prices. Finally, PT mechanism in Turkey is found to be much powerful and quick compared to similar countries (e.g. Brazil).

Volkan et al. (2007) compare pre-2003 and the post-2003 periods, when the exchange rates were allowed to float, by estimating two impulse-response functions and pass-through coefficients for these two different periods. They confirm that exchange rate shocks effect firstly manufacturers' prices and then consumer prices They also added that the impact of the exchange rate fluctuations on the price indexes of the different stages of the supply chain is different. Their findings state that the magnitude of the impact has diminish for the post-2003 period by nearly one-half compared to the pre-2003 period. They concluded that although there is a decline in the impact of pass through effect after 2003, when establishing monetary policies for the Turkish economy, pass through effect is still critical.

Yüncüler (2011) uses Cholesky decomposition and VAR methodology in Turkey's macroeconomic data between 1997-2010 (Yüncüler, 2011). Author analyzed the pass-through of changes in import prices and exchange rates on consumer and producer price indices. The results showed that both factors were more powerful on producer prices than consumer prices. However, it was found that the degree of transition decreased during the inflation targeting period. In addition, it was found that import price shocks were reflected to consumer prices more quickly than exchange rate shocks, whereas shocks to import prices were reflected to producer prices at a higher level than exchange rate shocks. 
Korkmaz and Bayır (2015), examined the relationship between the producer price index, consumer price index and the nominal effective exchange rate in Turkey between 2003 and 2014 (Korkmaz \& Bayır, 2015). Authors used Johansen causality test and showed a long-term relationship between these variables. The findings revealed causality from exchange rate to producer price index and consumer price index to exchange rate.

In another study, the relationship between inflation and the exchange rate in Turkey has been tested with VAR methodology between 1994 and 2014 (Bozdağlığlu \& Yılmaz, 2017). The depreciation of the exchange rate affected inflation, but the shocks in the inflation did not influence nominal exchange rate. According to these findings, authors argued that CBRT should favor the policies increasing the supply of foreign currency in order to control inflation.

Unlike previous studies, Göktaş (2019) studied the asymmetric relationship between the exchange rate and consumer prices in Turkey (Göktaş, 2019). The study, which examined the years 2003-2018, revealed that the relationship structure between $\mathrm{CPI}$ and nominal exchange rate basket fluctuations is not linear and these indicators move together in the long term. According to the results of the Nonlinear Boundary Test approach (NARDL), in the long term, CPI moves with exchange rate basket fluctuations. However, it is stated that increase in consumer prices caused by the appreciation of the foreign exchange basket is more than the decrease created in case the foreign exchange basket depreciates at the same rate.

\section{Data and Methodology}

This study examines the effects of exchange rates (US Dollar ${ }^{1}$ ) fluctuations (ER) on consumer price index (percentage change CPI) and producer price index (percentage change PPI) between 2003:01-2019:10 in Turkey. ${ }^{2}$ The data of series ${ }^{3}$ is obtained from the CBRT database. In order to test the existence of a longterm relationship between exchange rates and inflation, the boundary test approach and the ARDL method are used to investigate the long- and short-term relationship. The reasons for choosing this method in explaining the relationship between variables is that in cases where the degree of integration of the variables is not same $(I(0)$ and $I(1))$ and low data samples, these methods permit to investigate the relationship (Peseran et al., 2001).

Table 1. ER, CPI and PPI Variables Unit-Root Results (LEVEL)

\begin{tabular}{|c|c|c|c|c|c|c|c|c|c|}
\hline & \multicolumn{3}{|c|}{ ER } & \multicolumn{1}{c|}{ CPI } & \multicolumn{3}{c|}{ PPI } \\
\hline & ADF & PP & KPSS & ADF & PP & KPSS & ADF & PP & KPSS \\
\hline t-stat. & $3.4253(5)^{*}$ & $2.7495(5)$ & $1.3290(11)$ & $-2.1165(5)$ & $-6.9822(3)$ & $0.3563(9)$ & $-7.5427(1)$ & $-7.6340(1)$ & $0.2057(1)$ \\
\hline Prob. & 0.9999 & 0.9986 & & 0.0333 & 0.0000 & & 0.0000 & 0.0000 & \\
\hline Crit. Val. & & & & & & & & & \\
\hline$\% 1$ & -2.576814 & -2.576518 & 0.739000 & -2.576814 & -2.576518 & 0.739000 & -2.576576 & -2.576518 & 0.739000 \\
\hline$\% 5$ & -1.942456 & -1.942415 & 0.463000 & -1.942456 & -1.942415 & 0.463000 & -1.942423 & -1.942415 & 0.463000 \\
\hline$\% 10$ & -1.615622 & -1.615649 & 0.347000 & -1.615622 & -1.615649 & 0.347000 & -1.615644 & -1.615649 & 0.347000 \\
\hline
\end{tabular}

Table 1 shows the results of ADF, PP and KPSS tests for ER, CPI and PPI for the specified period in Turkey. ER series is not stationary at the level. Therefore, unit root tests will be applied to the first differences of this variable. According to the unit root test results applied to the first differences of ER, the series is stationary at first difference. ADF, PP and KPSS tests showed that CPI and PPI series are stationary (I(0)). 
Table 2. ER Variable 1st Difference Results

\begin{tabular}{|c|c|c|c|}
\hline & \multicolumn{3}{|c|}{ ER } \\
\hline & ADF & PP & KPSS \\
\hline t-stat & $-6.9310(4)^{*}$ & $-9.6205(1)^{*}$ & $0.6064(1)^{*}$ \\
\hline Probability & 0.0000 & 0.0000 & \\
\hline \multicolumn{4}{|l|}{ Critical Values } \\
\hline$\% 1$ & -4.005562 & -2.576576 & 0.739000 \\
\hline$\% 5$ & -3.432917 & -1.942423 & 0.463000 \\
\hline$\% 10$ & -3.140265 & -1.615644 & 0.347000 \\
\hline \multicolumn{4}{|c|}{$\begin{array}{l}\text { Tests have been applied to the none (no trend and constant) cases of the series. * Suitable } \\
\text { lag lengths. The Schwartz Criterion for ADF testing is the Newey-West bandwidth using the } \\
\text { Barlett kernel for PP and KPSS tests. }\end{array}$} \\
\hline
\end{tabular}

As it was found that ER series is stationary at first difference [I(1)] and CPI and PPI series are stationary at level [I(0)], ARDL (Autoregressive-Distributed Lag) method is suitable for investigating the cointegration relationship between the series.

When the figures 1 and 2 are examined, it is seen that it is necessary to generate a Zivot Andrews structural break unit root test to investigate the possibility of structural breaks in series.

Table 3. Zivot-Andrews Structural Break Unit Root Test Results

\begin{tabular}{|c|c|c|}
\hline Variables & Model & Break Dates \\
\hline ER & $-3.89(C)$ & $2014: 04$ \\
\hline$E R(1$ st dif.) & $-8.51(C)$ & $2016: 10$ \\
\hline CPI & $-9.73(C)$ & $2016: 11$ \\
\hline PPI & $-9.83(C)$ & \\
\hline$\% 1$ & Critical Values & \\
\hline$\% 5$ & -5.57 & \\
\hline$\% 10$ & -5.08 & \\
\hline \multicolumn{2}{|c|}{-4.82} & \\
\hline $\begin{array}{l}\text { The tests are conducted at level for all series at Model C (trend and constant) since ER series has a } \\
\text { trend as it seen in Figure } 2 .\end{array}$
\end{tabular}

Results suggests that ER series are I(1) and CPI and PPI series are I(0) with break dates 2016:10 for ER series, 2016:12 for CPI series and 2016:10 for PPI series. Therefore, dummies are added to the model to consider these break dates.

\subsection{Investigation of Cointegration and Bound Tests}

The relationship between these variables is investigated with the ARDL model using equations (1) and (2).

$$
\begin{aligned}
& \Delta \mathrm{CPI}_{\mathrm{t}}=\alpha_{0}+\sum_{i=1}^{m} \alpha_{1 \mathrm{i}} \Delta \mathrm{CPI}_{\mathrm{t}-\mathrm{i}}+\sum_{i=1}^{m} \alpha_{2 \mathrm{i}} \Delta \mathrm{ER}_{\mathrm{t}-\mathrm{i}}+\alpha_{3} \mathrm{CPI}_{t-1}+\alpha_{4} \mathrm{ER}_{t-1}+u_{t} \\
& \Delta \mathrm{PPI}_{\mathrm{t}}=\alpha_{0}+\sum_{i=1}^{m} \alpha_{1 \mathrm{i}} \Delta \mathrm{PPI}_{\mathrm{t}-\mathrm{i}}+\sum_{i=1}^{m} \alpha_{2 \mathrm{i}} \Delta \mathrm{ER}_{\mathrm{t}-\mathrm{i}}+\alpha_{3} \mathrm{PPI}_{t-1}+\alpha_{4} \mathrm{ER}_{t-1}+u_{t}
\end{aligned}
$$


When establishing ARDL models, bound test is performed to investigate whether there is a cointegration relationship. In this study, $\mathrm{F}$ bound test (Wald test) was applied.

Table 4. F-stat. Bound Test Results

\begin{tabular}{|c|c|c|}
\hline Eqn 1: F Stat & 31.558 & $\mathrm{k}=1$ \\
\hline Eqn 2: F Stat & 21.669 & $\mathrm{k}=1$ \\
\hline Significance Level & I(O) Bound Lower Limit & I(1) Bound Upper Limit \\
\hline $10 \%$ & 3.02 & 3.51 \\
\hline $5 \%$ & 3.62 & 4.16 \\
\hline $2.5 \%$ & 4.18 & 4.79 \\
\hline $1 \%$ & 4.94 & 5.58 \\
\hline
\end{tabular}

In Table 4, it is shown that there is a cointegration between the series because the test statistic for Equations 1 and 2 is above the lower and upper limit values.

Table 5. Toda-Yamamoto Causality Test Results

\begin{tabular}{|c|c|c|c|c|c|}
\hline & Null Hypotesis $\left(\mathrm{H}_{0}\right)$ & $\begin{array}{l}\text { Lag Lengths* } \\
\text { (K+Dmax) }\end{array}$ & Chi-sq & Prob. & Direction \\
\hline \multirow{2}{*}{ Eqn 1} & ER, does not Granger causality CPI & $8+1$ & 23.42349 & 0.0053 & \multirow{2}{*}{$\mathrm{ER} \leftrightarrow \mathrm{CPI}$} \\
\hline & CPI, does not Granger causality ER & $8+1$ & 27.20239 & 0.0013 & \\
\hline \multirow{2}{*}{ Eqn 2} & ER, does not Granger causality PPI & $6+1$ & 36.57084 & 0.0000 & $\mathrm{ER} \rightarrow \mathrm{PPI}$ \\
\hline & PPI, does not Granger causality ER & $6+1$ & 13.60208 & 0.1372 & PPIXER \\
\hline
\end{tabular}

${ }^{*}$ Lag Lengths are chosen according to LR, FPE and AIC.

Results show that there is a bidirectional causality between consumer price index and exchange rate and a unidirectional relation from exchange rate to producer price index. No causality is detected from producer price index to exchange rate.

Figure 3. Choosen ARDL Model according to Akaike I.C.

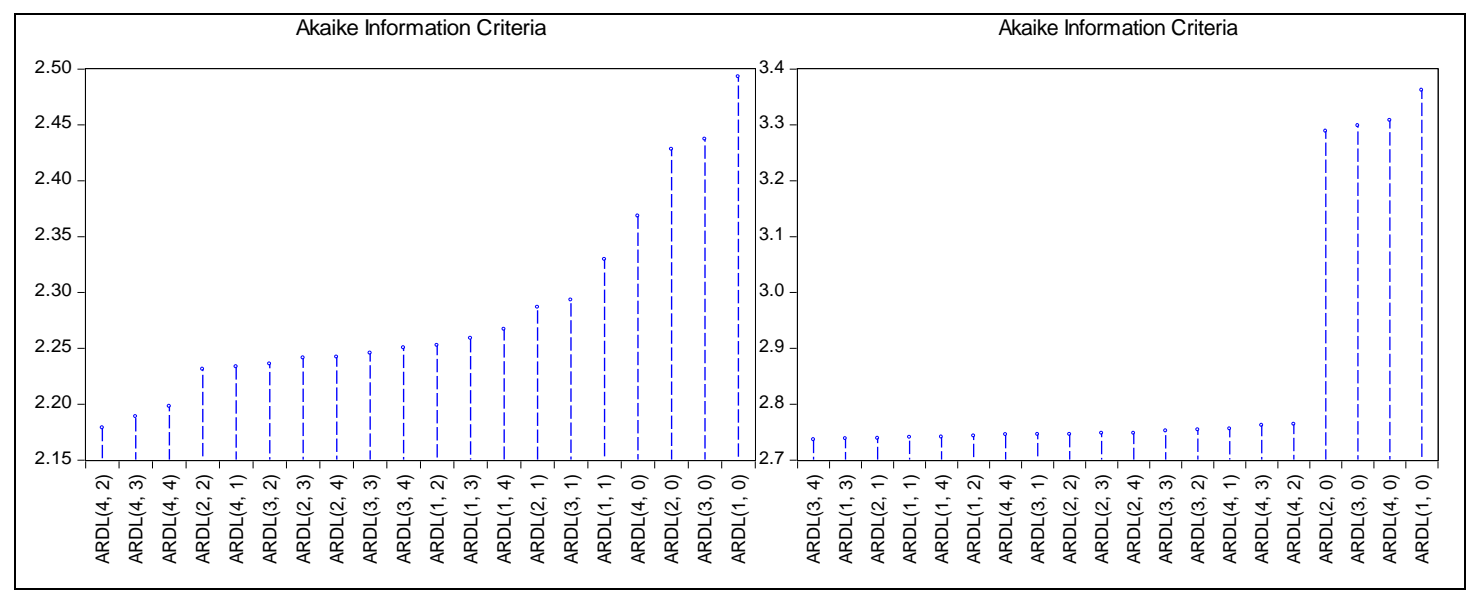

In Figure 3, lag lengths for Equation 1 and 2, AIC (Akaike), were examined. According to the Akaike information criterion, $\operatorname{ARDL}(4,2)$ for Equation 1 and $\operatorname{ARDL}(3,4)$ for Equation 2 provide the lowest information criterion value. 


\subsection{ARDL Model Estimation}

In order to estimate the coefficients of ARDL models, unrestricted error correction model (UECM) is established with dummy variables to consider structural break dates detected by Zivot Andrews test.

Tablo 4. ARDL $(4,2)$ and $\operatorname{ARDL}(3,4)$ Model Estimation Results

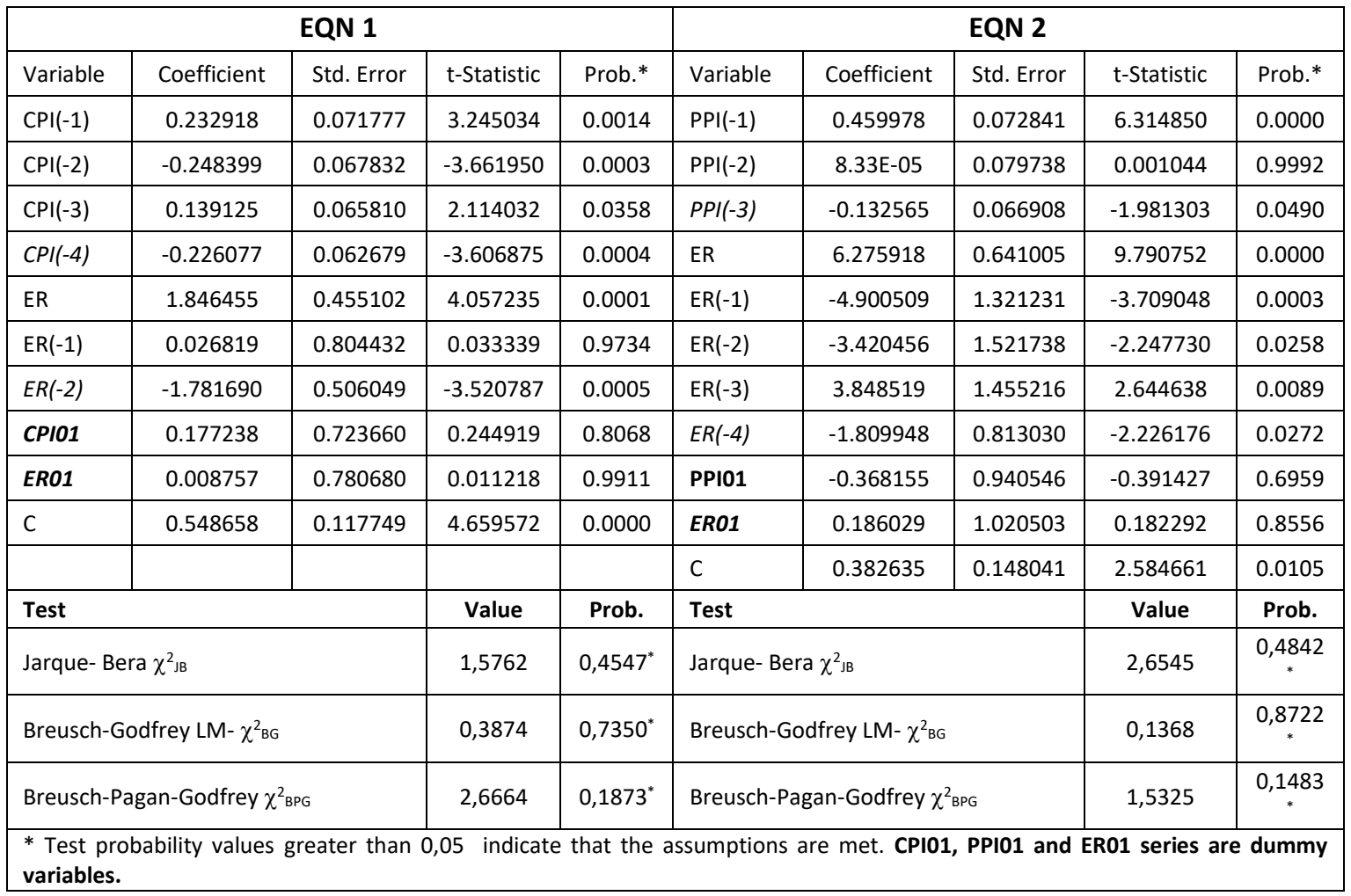

Autocorrelation, normality and heteroskedasticity tests were performed to determine the suitability of the model. Table 4 summarizes ARDL $(4,2)$ and ARDL $(3,4)$ model estimation results and diagnostic tests are shown.

Figure 4. Inverse Roots of AR for Model 1 and Model 2

Inverse Roots of AR Characteristic Polynomial Inverse Roots of AR Characteristic Polynomial

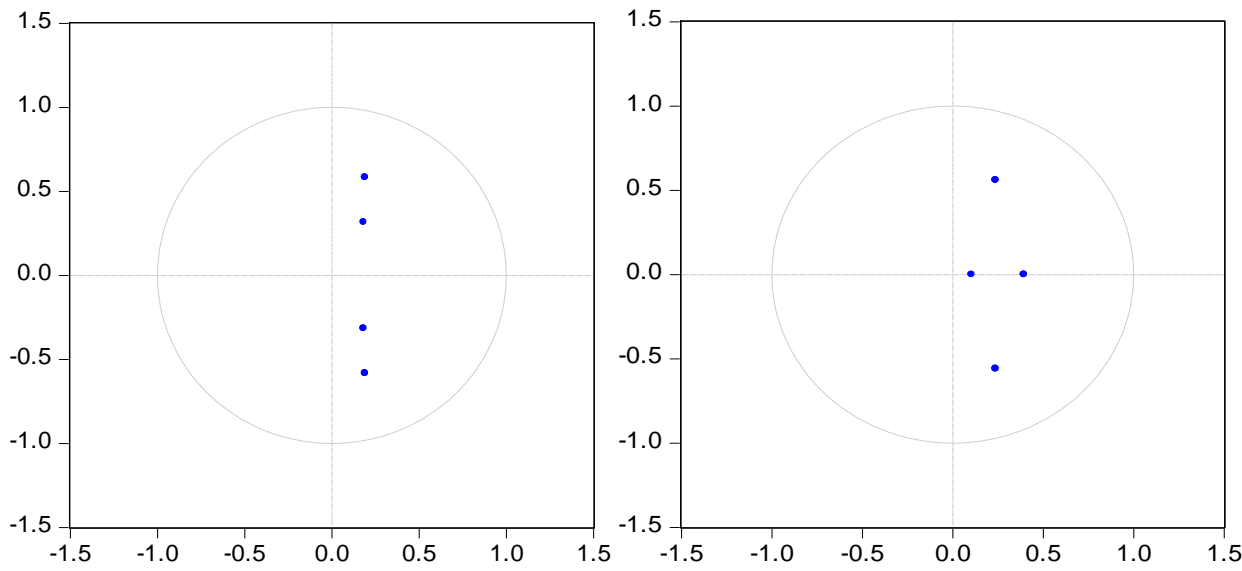

The predicted VAR model is stable because the inverse roots of the polynomial are located inside the unit circle in Figure 4. 


\subsection{Long and Short-run Relationship}

When we establish cointegration and suitable ARDL model, we can find a long term relationship between this variables according to equations 1 and equation 2. Long-term coefficients are given in Table 5.

Table 5. Long-Run Coefficients

\begin{tabular}{|c|c|c|c|c|c|}
\hline \multirow{4}{*}{ Eqn 1 } & Variables & Coefficient & St.Er. & t-stat & Prob. \\
\cline { 2 - 6 } & ER & 0.083074 & 0.039027 & 2.128650 & 0.0346 \\
\cline { 2 - 6 } & CPI01 & 0.160770 & 0.657821 & 0.244397 & 0.8072 \\
\cline { 2 - 6 } & ER01 & 0.007944 & 0.708118 & 0.011218 & 0.9911 \\
\cline { 2 - 6 } & $\mathrm{C}($ Constant T.) & 0.497680 & 0.096344 & 5.165677 & 0.0000 \\
\hline \multirow{4}{*}{ Eqn 2 } & Variables & Coefficient & St.Er. & t-stat & Prob. \\
\cline { 2 - 6 } & ER & -0.009631 & 0.089213 & -0.107958 & 0.9141 \\
\cline { 2 - 6 } & PPI01 & -0.547439 & 1.396975 & -0.391875 & 0.6956 \\
\cline { 2 - 6 } & ER01 & 0.276622 & 1.516098 & 0.182456 & 0.8554 \\
\cline { 2 - 6 } & $\mathrm{C}($ Constant T.) & 0.568971 & 0.212740 & 2.674483 & 0.0081 \\
\hline
\end{tabular}

When the coefficients are examined, since the coefficient of ER variable in Equation 1 is positive and significant at $5 \%$, there exists a relationship between exchange rate and $\mathrm{CPI}$ in long term. When the coefficients are examined for Equation 1, it is shown that a increase in exchange rates, generates low increase in $\mathrm{CPI}$ in long term. For Equation 2, the coefficient of ER is negative and statistically not significant, indicating there is no long term relationship between exchange rate and PPI.

The short-run relationship between the variables was estimated based on the error correction model given in Equation 3 and 4 below.

$$
\begin{aligned}
& \Delta C P I=\alpha_{0}+\sum_{i=1}^{m} \alpha_{1 i} \Delta C P I_{t-i}+\sum_{i=1}^{n} \Delta E R_{t-i}+\delta E C T_{t-1}+\varepsilon_{t} \\
& \Delta P P I=\alpha_{0}+\sum_{i=1}^{m} \alpha_{1 i} \Delta P P I_{t-i}+\sum_{i=1}^{n} \Delta E R_{t-i}+\delta E C T_{t-1}+\varepsilon_{t}
\end{aligned}
$$

Table 6. Short-Run Coefficients

\begin{tabular}{|c|c|c|c|c|c|}
\hline \multirow{4}{*}{ Eqn 3 } & Variables & Coefficient & St.Er. & t-stat & Prob. \\
\cline { 2 - 6 } & $D E R(-1)$ & 1.801452 & 0.488557 & 3.687293 & 0.0003 \\
\cline { 2 - 6 } & $E C T_{t-1}$ & -1.110480 & 0.111620 & -9.948788 & 0.0000 \\
\hline \multirow{3}{*}{ Eqn 4 } & Variables & Coefficient & St.Er. & t-stat & Prob. \\
\cline { 2 - 6 } & $D E R(-3)$ & 1.814495 & 0.807685 & 2.246537 & 0.0258 \\
\cline { 2 - 6 } & $E C T_{t-1}$ & -0.673067 & 0.082973 & -8.111919 & 0.0000 \\
\hline
\end{tabular}

When the coefficients are examined for Equation 3 and Equation 4, depreciation in ER causes increase in CPI. Similar results are found for the relation between ER and PPI.

The results in Table 6 show that error correction term both equations is statistically significant and negative as expected. 
Figure 5. CUSUM and CUSUMQ Results

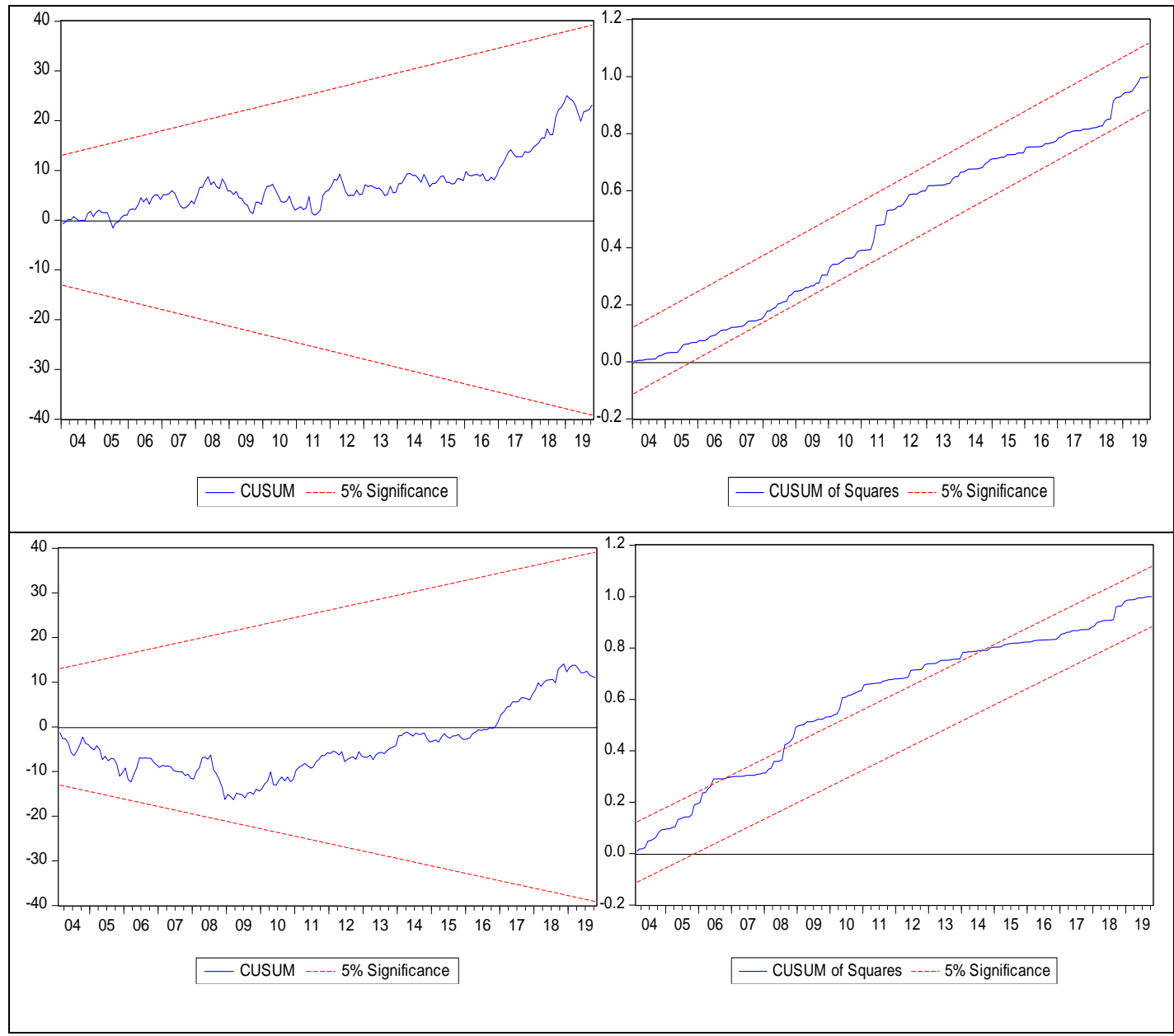

The graphs of the CUSUM and CUSUMQ tests demonstrate whether the long-term coefficients are stable as shown in Figure 5. The cumulative sum of the residues and residual squares of the long-term model (excluding CUSUMQ for Equation 1) is within 5\% critical lines. Thus, coefficients of Equation 1 are stable, however long-term coefficients of Equation 2 are insignificant and unstable.

\section{Conclusion}

In this study, the short-term and long-term relationships between Exchange rate (US Dollar), consumer price index and producer price index is examined between 2003:01-2019:10 in Turkey. Toda Yamamato test results show that fluctuations in exchange rate cause changes in both consumer and producer price indexes. These findings support the hypothesis that the pass-through mechanism is effective in Turkey.

When the short-run relationship between exchange rate and consumer price index is examined, it is evident a depreciation in exchange rates in Turkey causes increase in CPI. Besides, similar results are found for the relationship between exchange rate and PPI in short term. In other words, a depreciation in exchange rates increases PPI by increasing costs, especially over energy and raw material prices. According to these results, the fluctuations of exchange rates have serious effects on inflation rate in the short run. These findings show a remarkable similarity with the outcomes in the inflation report of CBRT in 2016 (2016-I).

As for the long run, despite weakening, the relationship between exchange rate and consumer price index is still persistent. On the contrary, the relationship between exchange rates and producer price index is statistically insignificant in the long run. A similar finding is demonstrated by Zorzi, Hahn and Sanchez (2007) where they don't find a long term relationship between ER and PPI. Moreover, Leigh and Rossi (2002) 
showed that PT mechanism is very strong in first 4 months and completed over a period of 11 months in Turkey.

According to these results; in Turkey, the pass-through effect appears to be quite powerful, especially in the short run. In order to achieve price stability, which is the main objective of the Central Bank, the fluctuations in exchange rate should be considered. Therefore; CBRT should give priority to the policies that take into account the fluctuations in exchange rate to achieve its inflation target. In addition, overshooting the inflation target affects negatively the expectations of all producers and consumers which leads to dollarization and causes deterioration in cost structures with the expectation that prices will rise and increases the pass-through effect. Structural improvements in economy and in money policies will provide an environment in which domestic prices have a stronger structure against short and long-run effects of exchange rate.

This study examines the relationship between exchange rates and price indexes excluding the effects of other variables that might influence price indexes such as oil prices as supply shocks, monetary policies and demand shocks. Therefore, it would be a valuable contribution to the literature if these variables are also considered in future studies.

\section{Disclosure Statements}

1. The authors of this article are admitted that they complied with the principles of research and publication ethics.

2. No potential conflict of interest was reported by the authors.

3. This article was screened for potential plagiarism using a plagiarism screening program.

\section{End Notes}

1. Since approximately $60 \%$ of the imports of Turkey is made in US Dollar in the examined years, USD dollar is used for the exchange rate variable.

2. The reason for selecting this period is that; the CBRT and government abandoned the fixed exchange rate regime and adapted the floating exchange rate regime after 2001 crisis. Besides, CBRT implemented the implicit inflation targeting strategy as a main anchor as of 2002.

3. CPI and PPI series are seasonality adjusted.

\section{References}

Bozdağlığlu, E. Y., \& Yılmaz, M. (2017). Türkiye'de enflasyon ve döviz ilişkisi: 1994-2014 yılları arası bir inceleme. Bitlis Eren Üniversitesi Akademik İdüşüm Dergisi, 2(3), 1-20.

Ca' Zorzi, M., Hahn, E., \& Sánchez, M. (2007). exchange rate pass-through in emerging markets. ECB Working Paper, No. 739, European Central Bank (ECB).

CBRT, EVDS. https://evds2.tcmb.gov.tr/_(Access Date: 12 Dec. 2019).

CBRT, Inflation Report, 2016-I. https://www.tcmb.gov.tr/wps/wcm/connect/TR/TCMB+TR/Main+Menu/Yayinlar/Raporlar/Enflasyon+Raporu/ 2016/Enflasyon+Raporu+2016-I (Access Date: 02 Dec. 2019).

CBRT, Inflation Report, 2018-IV. https://www.tcmb.gov.tr/wps/wcm/connect/TR/TCMB+TR/Main+Menu/Yayinlar/Raporlar/Enflasyon+Raporu/ 2018/Enflasyon+Raporu+2018-IV (Access Date: 02 Dec. 2019).

Dornbusch, R. (1987). Exchange rates and prices. American Economic Review, 77(1), 93-106.

Göktaş, P. (2019). Asymmetric transition effects of the exchange rate on consumer prices in Turkey. Sosyoekonomi, 27(42), 29-50. 
Goldberg, P. K., \& Knetter, M. M. (1996). Good prices and exchange rate: What have we Learned? NBER Working Paper 5862.

Helali, K., Kalai, M., \& Boujelben, T. (2015). Exchange rate Pass-Through to domestic prices in Tunisia : A short and long run analysis. MPRA Paper, (62204).

Ito, T., \& Sato, K. (2008). Exchange rate changes and inflation in post-crisis Asian economies: Vector autoregression analysis of the exchange rate pass-through. Journal of Money, Credit and Banking, 40(7), 1407-1438.

Korkmaz, S., \& Bayır, M. (2015). Döviz kuru dalgalanmalarının yurtiçi fiyatlara etkisi. Niğde Üniversitesi iktisadi ve idari Bilimler Fakültesi Dergisi, 8(4), 69-85.

Leigh, D., \& Rossi, M. (2002). Exchange rate Pass- Through in Turkey. IMF Working Paper, https://www.imf.org/external/pubs/ft/wp/2002/wp02204.pdf (Access Date: 2 July 2018.

María-Dolores, R. (2009). Exchange rate pass-through in Central and East European countries. Eastern European Economics, 47(4), 42-61.

McCarthy, J. (1999). Pass-through of exchange rates and import prices to domestic inflation in some industrialised economies. Bank for International Settlements, 1-36.

Menon, J. (1994). Flexible exchange rates and traded goods prices: A theory of the short-run. Economia Internazionale/International Economics, 47(1), 55-68.

Menon, J. (1996). The degree and determinants of exchange rate pass-through: Market structure, non-tariff barriers and multinational corporations. The Economic Journal, 106(435), 434-444.

Pesaran, M. H, Yongcheol S., \& Richard, J. S. (2001). Bounds testing approaches to the analysis of level relationships. Journal of Applied Econometrics, 16(3), 289-326.

Saha, S., \& Zhang, Z. (2013). Do exchange rates affect consumer prices? A comparative analysis for Australia, China and India. Mathematics and Computers in Simulation, 93(2010), 128-138.

Taylor, J. B. (2000). Low inflation, pass-through, and the pricing power of firms. European Economic Review, 44(7), 13891408.

TUiK, Dış Ticaret İstatistikleri, http://tuik.gov.tr/PreTablo.do?alt_id=1046 (Access Date: 20 Oct. 2019).

Volkan, A., Saatçioğlu, C., \& Korap, L. (2007). Impact of exchange rate changes on domestic inflation: The Turkish experience .Discussion Paper, No. 2007/6, Turkish Economic Association.

Yüncüler, Ç. (2011). Pass through of external factors into price indicators in Turkey. Central Bank Review, 11, 71-84. 